\title{
Benchmark study on effect of Trypanosome brucei using Moringaoleifera seed extract and Honey as treatment measure(s).
}

\author{
Amadi, E. $\mathrm{N}^{1}$, Okereke, C. $\mathrm{N}^{2}$, Njoku, O. O ${ }^{3}$, Ndubuisi, J. L4, Ekwealor, K. U ${ }^{5}$ \\ ${ }^{I}$ Department of Zoology, NnamdiAzikiwe University, Awka, Anambra, Nigeria. \\ ${ }^{2}$ Department of Applied Biology, Ebonyi State University, Abakaliki, Ebonyi, Nigeria. \\ ${ }^{3}$ Department of Biology, Federal University of Technology, Owerri, Imo, Nigeria. \\ ${ }^{4}$ Department of Botany, NnamdiAzikiwe University, Awka, Anambra, Nigeria. \\ ${ }^{5}$ Department of Botany, NnamdiAzikiwe University, Awka, Anambra, Nigeria.
}

\begin{abstract}
Moringaoleifera is a pan-tropical species that is reputed to possess a number of nutritional and medicinal properties. On the other hand, honey is widely known for its anti-trypanocidal effects. The effect of various doses of aqueous extract of Moringaoleifera seed on the activities of the White Blood Cells (WBC) and Red Blood Cells (RBC) was investigated. Daily-dose administration of the Moringa seed treated water $(1-10$ $\mathrm{mg} / \mathrm{ml}$ ) to different rat groups for 21 days resulted in significant increase $(P>0.05)$ in the activities of the RBC and $W B C$ were seen to have their influence in fighting the disease Trypanosomiasis. Histopathological studies revealed the presence of marked aggregation of bile canaliculi around the portal vein of the liver. Aqueous extract of Moringaoleifera leaves also delayed the proliferation of the parasites. Honey has properties of boosting the immune system, its anti-inflammatory action, antioxidant activity and stimulation of cell growth. Anaemia and serum biochemical changes are common features of African trypanosomosis. We investigated whether honey has protective effect on some liver functions and blood parameters affected by trypanosome infection. The serum albumin concentration in infected untreated rats increased significantly $(p<0.05)$ compared with control whereas treatment with honey returned this effect to normal values.
\end{abstract}

Keyword:Moringaoleifera seed extract, honey, toxicity, parasitaemia, metabolic enzymes.

\section{Introduction}

Animal trypanosomiasis is still a major factor ravaging the growth of the livestock industry in Africa.Trypanosomiasis, a disease of major importance in human and animals has continued to threaten human health and economic development of the affected areas (9). World health organization report that 66 million people in 36 African countries are affected and animal trypanosomiasis causes the death of 3 million cattle each year (8). The control of this disease relies principally on old chemotherapy and chemoprophylaxis. (3). Thus is due to the nature of insects that are prone to this Sub-Saharan desert like tsetse flies. About 31 species of Glossina in Africa, 11 species are known to play important role in transmitting the infection to mane.gGlossinamorsitan subspecies. Focus on plant research has increased in recent times all over the world and the results have shown an immense potential of some plants in traditional water purification system (2). Sporadic cases usually arise from among those in the population whose activities bring them into contact with the savannah woodland habitats of the Glossinamorsitan group (6). Moringaoleifera is one of the widely most cultivated monogeria family.Moringaceae quick growing: hence the most widely distributed botanical worldwide. All parts of Moringa are edible and with or useful to animals and man. The leaves of $M$. oleiferahave been reported to be a valuable source of both macro and micro nutrient, rich source of Betacarotene, protein, vitamin $\mathrm{C}$, calcium and potassium and act as a good source of natural oxidants, and thus enhance the shelf life of fat containing food (7). Trypanosomiasis in rats is associated with a decreased serum protein as infection progressed. Improvement on host's nutrition is important in moderating the severity of pathophysiological effect of trypanosomiasis and also influences the rate of recovery(4). It was discovered that supplementary feeding significantly reduces the severity of trypanosomiasis. 
Fig 1: Moringaoleifera flowering plant and Glossina forms of Trypanosomabruceiobserved in the tsetse fly and in the host human blood stream.

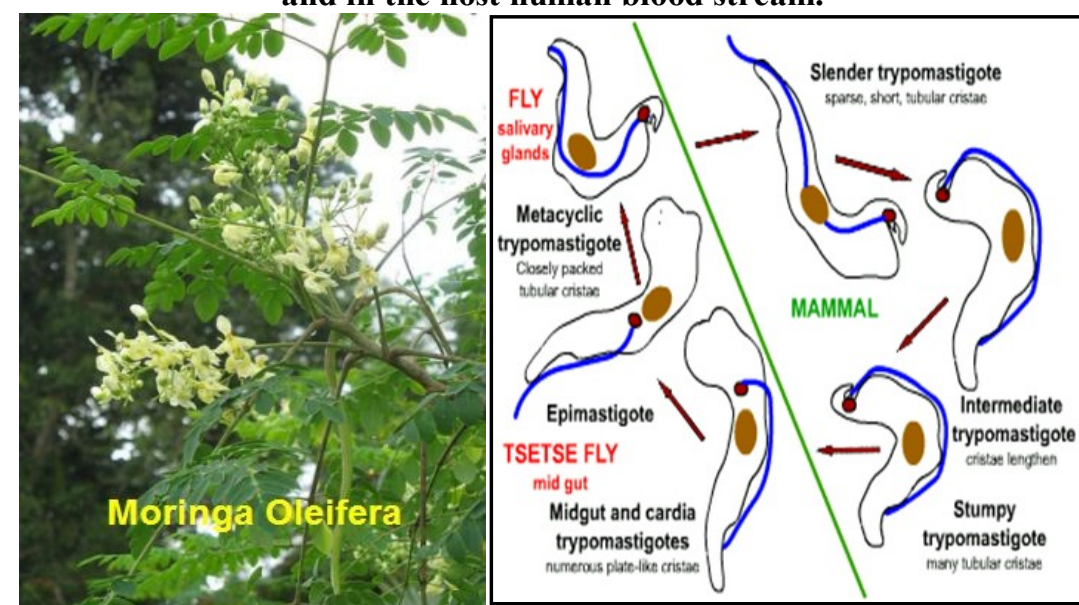

Figure 2: Infected tsetse fly injects metacyclictrypomastigotes into the skin tissue of the mammalian host.

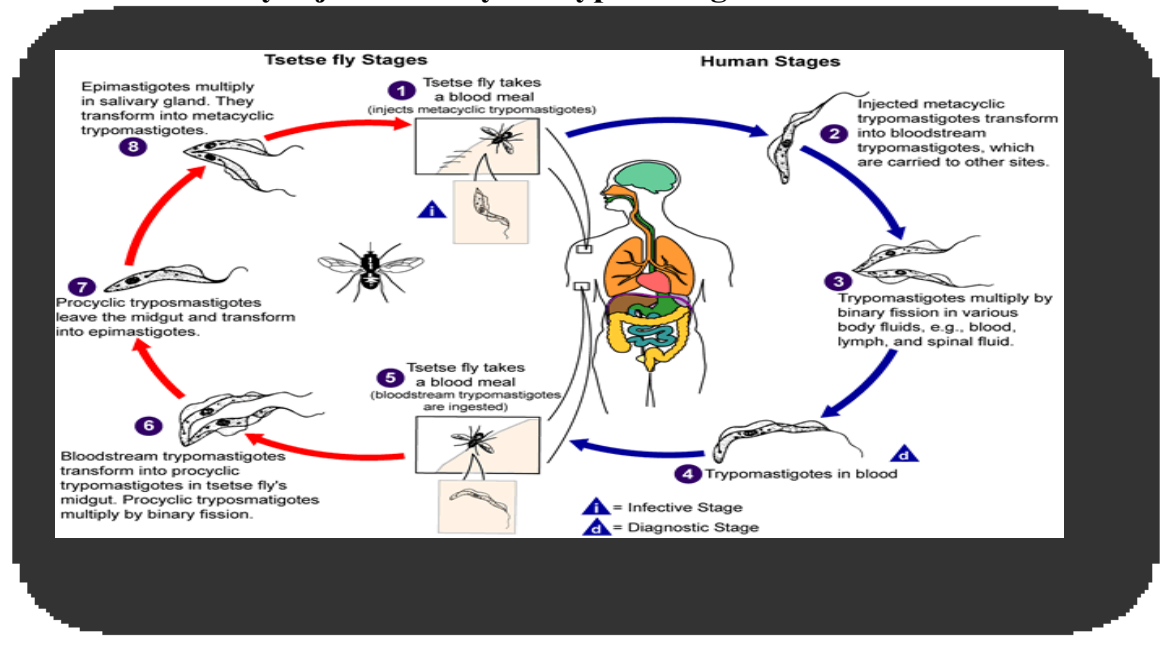

\section{Source of materials}

\section{Materials And Methods}

M. oleifera seeds and natural honey were harvested from Awo-Omamma, a town in Oru-East Local Government Area in Imo State and transported in a cool van $\left(20^{\circ} \mathrm{C}\right)$ to the Laboratory of the Department of Zoology, NnamdiAzikiwe University, Awka, Nigeria. The sample was later air dried at $100^{\circ} \mathrm{C}$ for $24 \mathrm{~h}$ and ground to a powdery form. Extraction of Moringa seed was done using water treatment. Five hundred gram of the powdered M. oleifera seed was soaked in $200 \mathrm{ml}$ distilled water at ambient temperature for three days and filtered. The bulked filtrate was reduced in vacuole at $40^{\circ} \mathrm{C}$. The residue was later stored at $-4^{\circ} \mathrm{C}$ until it was needed. Varied concentrations $(1-10 \mathrm{mg} / \mathrm{ml})$ of the extract were used for the treatment of well water

\section{Material and Methods} Animals:

Twenty adult albino rats were obtained from our Saviour Research Institute, Awka, Nigeria. The animals were acclimatized to the laboratory conditions and a commercial pelleted poultry grower's mash diet was given to the animals for 2 weeks before commencement of the experiment for the animals to acclimatize. The animals were then divided into four groups of rats each and treated as follows:

\section{Uninfected controls:}

The five rats in this group were neither infected nor treated with theextract.

\section{Extract control:}

This group consisted of five uninfected rats that were given, ad libitum, Moringaoleifera extract as drinking water. 


\section{Infected controls:}

Five rats were each intraperitoneally infected with about $10^{6}$ Trypanosomabrucei in $0.5 \mathrm{ml}$ of cold-saline diluted tail-blood from a donor rat.

\section{Infected and Extract-treated group:}

The rats in this group were similarly infected with parasites and maintained, ad libitum on aqueous Moringaoleifera extract as drinking water. Each experimental set up was replicatedthree times.

\section{The parasites:}

The Trypanosomabrucei used for the study was obtained from the Veterinary Medicine Faculty, University of Nigeria, Nsukka. Each of the recipient animals was inoculated with $10^{6} \mathrm{~T}$. brucei.

\section{Determination of degree of parasitaemia: \\ Film preparation:}

A drop of blood was taken from the tail vein of the infected rats and placed at distance of about an inch from one end of the microscopic slide and dispersed along the length of the slide with one another. The film formed was air-dried and then fixed with leishmann stain. After rinsing with distilled water and leaving it to airdry, the slide was put under oil immersion and numbers of parasites per 1000 red blood cell were counted. Bleeding and analysis of the haematological parameters: At the end of the experiments, each animal was anaesthesized with chloroform and sacrificed by cutting through the jugular vein. The blood pooled from all the animals in each group was collected into bottles containing EDTA as anticoagulant. The red blood cells (RBC) and white blood cells (WBC) were estimated using the improved Neubauer counting chamber.

\section{Statistical Analyses:} 2-way ANOVA.

The data were presented as means of SEM of three replicates values. The data were determined using

\section{Result}

Table 1:TheRed Blood Cell (RBC) count $\left(\times 10^{6}\right)$ of $T$. brucei infected and uninfected/control rats treated with Honey and Moringaoleifera extract supplement.

\begin{tabular}{|l|l|l|}
\hline Honey Supplement & RBC of Infected Rats & RBC of Uninfected Rats \\
\hline Day 1 & 3.73 & 3.40 \\
\hline Day 7 & 3.53 & 3.88 \\
\hline Day 14 & 3.37 & 4.28 \\
\hline Day 21 & 0.00 & 4.15 \\
\hline Average & $\mathbf{3 . 5 4}$ & $\mathbf{3 . 9 3}$ \\
\hline
\end{tabular}

\begin{tabular}{|l|l|l|}
\hline MoringaExtract Supplement & RBC of Infected Rats & RBC of Uninfected Rats \\
\hline Day 1 & 3.70 & 3.30 \\
\hline Day 7 & 3.47 & 3.77 \\
\hline Day 14 & 3.32 & 4.08 \\
\hline Day 21 & 0.00 & 4.20 \\
\hline Average & $\mathbf{3 . 5 0}$ & $\mathbf{3 . 8 4}$ \\
\hline
\end{tabular}

\begin{tabular}{|l|l|l|}
\hline Honey and Moringa Extract Supplement & RBC of Infected Rats & RBC of Uninfected Rats \\
\hline Day 1 & 3.72 & 3.25 \\
\hline Day 7 & 3.58 & 4.03 \\
\hline Day 14 & 3.47 & 4.18 \\
\hline Day 21 & 0.00 & 4.47 \\
\hline Average & $\mathbf{3 . 5 9}$ & $\mathbf{3 . 9 8}$ \\
\hline
\end{tabular}

Table 2:TheWhiteBlood Cell (WBC) count $\left(\times 10^{3}\right)$ of T. brucei infected and uninfected/control rats treated with Honey and Moringaoleifera extract supplement.

\begin{tabular}{|l|l|l|}
\hline Honey Supplement & WBC of Infected Rats & WBC of Uninfected Rats \\
\hline Day 1 & 13.18 & 13.02 \\
\hline Day 7 & 14.28 & 14.50 \\
\hline Day 14 & 14.49 & 14.83 \\
\hline Day 21 & 0.00 & 15.40 \\
\hline Average & $\mathbf{1 3 . 8 4}$ & $\mathbf{1 4 . 4 4}$ \\
\hline
\end{tabular}




\begin{tabular}{|l|l|l|}
\hline Moringa Extract Supplement & WBC of Infected Rats & WBC of Uninfected Rats \\
\hline Day 1 & 13.85 & 12.97 \\
\hline Day 7 & 14.28 & 14.72 \\
\hline Day 14 & 14.49 & 15.18 \\
\hline Day 21 & 0.00 & 15.58 \\
\hline Average & $\mathbf{1 4 . 2 1}$ & $\mathbf{1 4 . 6 1}$ \\
\hline
\end{tabular}

\begin{tabular}{|l|l|l|}
\hline Honey and Moringa Extract Supplement & WBC of Infected Rats & WBC of Uninfected Rats \\
\hline Day 1 & 13.48 & 12.96 \\
\hline Day 7 & 14.05 & 14.72 \\
\hline Day 14 & 14.50 & 15.18 \\
\hline Day 21 & 0.00 & 15.58 \\
\hline Average & $\mathbf{1 4 . 0 1}$ & $\mathbf{1 4 . 6 1}$ \\
\hline
\end{tabular}

Table 1: represent the RBC count of the experimental rats at Days 1, 7, 14, and 21 and Average of the post infection. The lowest mean of the RBC count was $3.50 \times 10^{6}$ of the infected rats treated with Moringaoleifera Extract supplement, while the highest RBC count was found in $3.98 \times 10^{6}$ of the honey treated supplement of the uninfected rats. However, table 2 represent the WBC count of the experimental rats at Days $1,7,14$, and 21 and Average of the post infection. The lowest mean of the WBC count was $13.84 \times 10^{3}$ of the infected rats treated with honey supplementation, while the highest mean of the WBC count was seen in $14.61 \mathrm{x}$ $10^{3}$ of the uninfected rats treated with honey and Moringaoleifera Extract.

\section{Discussion}

The presence of hydrogen peroxide level of honey credits its ability to maintain low parasitaemia in trypanosome infected rats as the parasite do not possess high-classed mechanism for metabolizing hydrogen peroxide. It should as well be of note that $T$. brucei digests lots of glucose as its food that makes it easier for honey to work against the parasitemia progress in honey supplemented food regimen. This is due to the fact that honey has a high level of carbohydrate composition which includes other carbohydrate composition like fructose, maltose, galactose etc. These may work against the existence of parasitaemia in the rats. Moringaoleiferais one of the several scientific researches that have been done in trying to identify and standardized active food supplement that would be active in treatment of trypanosomiasis. The experimental albino rats well tolerated the M. oleifera seed extract thus gave a high positive result. However, our result is in unison with potent antioxidant activity of aqueous extract of M.oleifera which adds one more positive attribute to its pharmachological properties. Honey stimulates monocytes in cell cultures to release the cytokines, TNFalpha, IL -1 and IL-6, the cell messengers that activate many facets of the immune response to infection (1). In stimulation of these leucocytes, honey provide supply of glucose which is essential for the respiratory burst in macrophages that produce hydrogen peroxide the main component that attacked cell membrane of the parasite (5).

\section{References}

[1]. Abuharfeil, N., Aloran, R. and Aboshehada, M. (1999). The effect of bee honey on the proliferation activity of human B-and Tlymphocytes and the activity of phagocytes. Food and Agric. Immunol. 11: 169-177

[2]. Amaglah FK, Benanng A (2009). Effectiveness of Moringaoleifera seed as coagulant for water purification. Afr. J. Agric. Res. 4(1):119-123.

[3]. Anene, B. M., Onah, D. N. and Nawa, Y. (2001). Drug resistance in pathogenic African trypanosomes. What hopes for the future? Vet.Parasitol. 96:83-100.

[4]. Katungka-Rwakishaya, E. (1996). Interaction between animal nutrition and Parasites, studies with experimental trypanosomiasis in sheep. Pages 1-9. in (Lebbie, S.H.B. and Kagwini, E., Eds). Small Ruminant Research and development in Africa. International Livestock Research Institute (ILRI) Nairobi Kenya.

[5]. Molan, P. C. (2001). Why honey is effective as a medicine. The scientific explanation of its effects. Bee World 82: 22-40.

[6]. Pentreath VW and Kennedy GE (2004). Pathogenesis of human African trypanosomiasis (eds. 1. Mandlin, P.H. Holmes and Miles) CABI publishing, Pg. 283-301.

[7]. Siddhuraju P. and Becker, K. (2003) "Antioxidant properties of various solvent extracts of total phenolic constituents from three different agroclimatic origins", Food Chemistry, vol.5 1, no.8, PP. 2144-2155.

[8]. Truc, P., Lejon, V. and Magnus, E. (2002). Evaluation of the micro-CATT, CATT/Trypanosomabruceigambiense and LATEX/ T. B. gambiensemethods for serodiagnosis and surveillance of human African trypanosomiasis in West and Central Africa. Bulletin of worldHealth Organization. 80(11):882-886.

[9]. World Health Organization (2009). Mortality and Health data and statistics. 